\title{
ARE DISCOVERY LEARNING AND INDEPENDENT LEARNING EFFECTIVE IN IMPROVING STUDENTS' COGNITIVE SKILLS?
}

\author{
Wira Novantri ${ }^{{ }^{*}}$, Maison ${ }^{2}$, Muslim $^{3}$, Lusi W. Aftriyati ${ }^{4}$ \\ ${ }^{1,2,3}$ Department of Mathematics Education, Postgraduate Program, Universitas Jambi, Indonesia \\ ${ }^{4}$ Department of Mathematics Education, Postgraduate Program, Universitas Riau, Indonesia \\ *Corresponding author: wiranovantri95@gmail.com
}

\begin{tabular}{l}
\hline Article Info \\
\hline Article history: \\
Received: June 16, 202020 \\
Accepted: July 30, 2020 \\
Published: July 31, 2020
\end{tabular}

\section{Keywords:}

Android application Discovery learning Independent learning Mathematics learning outcomes

\begin{abstract}
Based on the theory, the success of students in learning is determined by learning model applied by the teacher and students' independent learning skills. This research is a quasi experimental research with pretest and posttest design. The population of this research was students of class XI SMA N 3 Tebo in 2019/2020 academic year. The sampling technique used cluster random sampling. The research instruments used mathematical cognitive tests and student independent learning questionnaires. The data analysis technique used is two-way variance analysis with $3 \times 3$ factorial design. Based on the results of this researh, we can concluded that (1) There is a difference in the average of students' mathematics cognitive skills based on the applied learning model, (2) There are differences in the average of students mathematics cognitive learning outcomes based on the level of independent learning, (3) there is no interaction between Discovery learning model and independent learning towards students' mathematics cognitive skills.
\end{abstract}

\section{APAKAH PEMBELAJARAN DISCOVERY DAN KEMANDIRIAN BELAJAR EFEKTIF DALAM MENINGKATKAN KEMAMPUAN KOGNITIF SISWA?}

ABSTRAK
Berdasarkan teori, keberhasilan siswa dalam pembelajaran
ditentukan oleh model pembelajaran yang diterapkan oleh guru
serta kemandirian belajar yang dimiliki oleh seorang siswa.
Penelitian ini adalah penelitian Quasi Eksperimental dengan desain
pretest and posttest design. Populasi penelitian adalah siswa kelas
XI SMA N 3 Tebo tahun ajaran $2019 / 2020$. Teknik pengambilan
sampel menggunakan Cluster Random Sampling. Instrumen
penelitian yang digunakan adalah tes kognitif matematika dan
angket kemandirian belajar siswa. Teknik analisis data yang
digunakan adalah analisis variansi dua jalur dengan desain faktorial
$3 \times 3$. Berdasarkan hasil penelitian didapat kesimpulan bahwa (1)
Terdapat perbedaan rata-rata kemampuan kognitif matematika
siswa berdasarkan model pembelajaran Discovery Learning, (2)
Terdapat perbedaan rata-rata kemampuan kognitif matematika
siswa berdasarkan tingkat kemandirian belajar siswa, (3) tidak
terdapat interaksi model pembelajaran Discovery Learning dan
kemandirian belajar siswa terhadap kemampuan kognitif
matematika siswa.

\section{Kata Kunci:}

Aplikasi android

Pembelajaran discovery

Kemandirian belajar

Hasil belajar matematika 


\section{INTRODUCTION}

Students need to have mathematics skills in facing global challenges, therefore learning mathematics is very important. Mathematics learning is able to build student character based on 21st century abilities that can be applied in daily life [1]. Based on the role of mathematics in this century, mastery of mathematics is considered very important. But in reality, the process of learning mathematics in the classroom still does not meet expectations, so that, student mathematics learning outcomes are not optimal [2]. The low learning outcomes of mathematics is caused by students have difficulty in understanding mathematics concept and are easily bored during the learning process [3]. In addition, the knowledge obtained by students from schools is the result of teacher explanations, not from students' own searches. Students tend to be silent only when the teacher explains the material and students are asked to memorize concepts or formulas, so the concepts they get will be easily forgotten [4]. While ideal learning is meaningful learning, not just memorizing formulas to solve mathematical problems but students are also able to construct or build their own knowledge [5].

In learning mathematics, students are encouraged to find the completion of principles, concepts, and mathematical formulas in accordance with the learning designed by the teacher. Learning also provide as many opportunities as possible for students to solve mathematical problems and train students' potentials to obtain better learning outcomes [6]-[7]. Teachers must be able to choose innovative learning models, strategies, approaches, and methods in order to achieve successful mathematics learning [8]. According to Swaak, discovery learning ensures that students take an active role in building their own basic knowledge. In Discovery Learning, teachers can ask students to design their own experiments, create their own strategies, solve problems or answer questions from the teacher [9]-[10]. Based on previous research conducted by Arifin, it showed that there are differences in the average score of student learning outcomes in discovery-learning and student learning outcomes in Talking Stick learning [11]. In Discovery Learning (DL) students are actively involved in learning, so students can get maximum learning results [12]-[13].

Besides choosing the right learning model, student independence in learning also has a positive influence on student achievement [14]. Based on Handayani research, the correlation between independent learning with mathematics learning outcomes is the higher the level of independent learning, the higher the mathematics learning outcomes of students [15]. Learning outcomes do not only depend on face-to-face activities. Beside the structured tasks presented by the teacher, the independence of student learning also determines student learning outcomes [16]-[19]. Independent learning is one of the important behaviors in the process of learning mathematics. Therefore, we conduct research that aims to: (1) find out the difference in average scores of students' mathematics learning outcomes based on the Discovery Learning model, (2) find out the differences in average scores of students' mathematics learning outcomes based on the level of independent learning, and (3) determine the effect of the interaction of learning models and independent learning on student mathematics learning outcomes.

\section{METHOD}

This research is a quantitative research with a quasi-experimental method using pretest and posttest design [20]. The population in this study were students of class XI of SMA N 3 Tebo in 2019/2020 academic year. The sample selection used the Cluster Random Sampling technique because of the absence of a sample frame (list of names of all members of the population). Figure 1 shows the procedure of this research. 


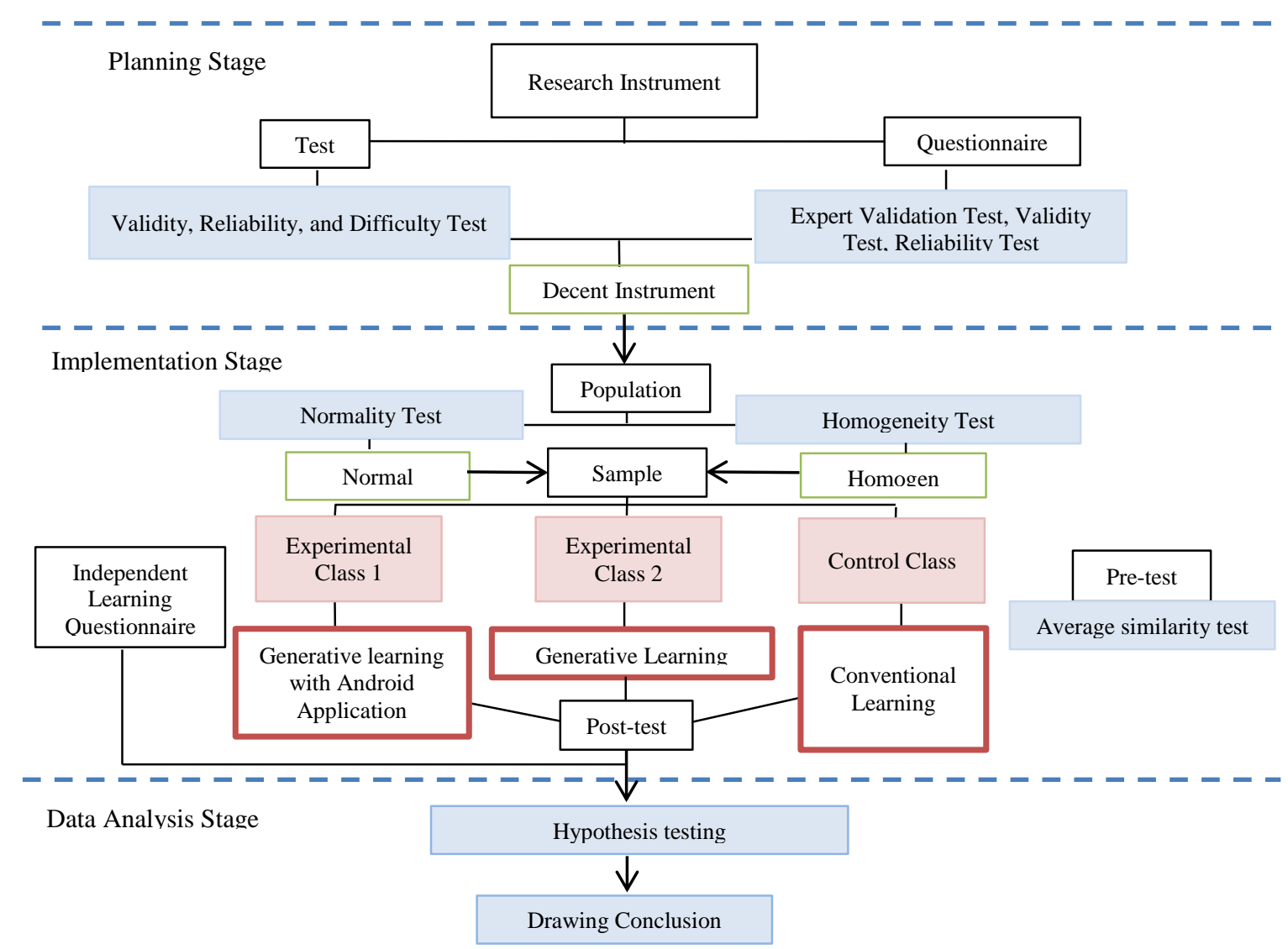

Figure 1. Research Procedure

In this study, there are two experimental classes and one control class with three different treatment types. In the experimental class 1 using Discovery Learning assisted with android applications, the experimental class 2 using Discovery Learning model, and control class using conventional learning model assisted by android application. Android application in this study contains mathematical topic with Sequences and Series subject which is equipped with teaching materials, examples of problems in everyday life, and videos that can be accessed offline. And conventional learning in this study referred to a learning that begins with the delivery of material, writing formulas or concepts, giving examples of questions, and providing exercises for students.

Table 1. Research Design

\begin{tabular}{cccc}
\hline Learning Model $\left(\boldsymbol{A}_{\boldsymbol{i}}\right)$ & \multicolumn{3}{c}{ Independent Learning $\left(\boldsymbol{B}_{\boldsymbol{i}}\right)$} \\
\cline { 2 - 4 } & High $\left(\boldsymbol{B}_{\mathbf{1}}\right)$ & Medium $\left(\boldsymbol{B}_{\mathbf{2}}\right)$ & Low $\left(\boldsymbol{B}_{\mathbf{3}}\right)$ \\
\hline Discovery Learning with android application $\left(A_{1}\right)$ & $A_{1} B_{1}$ & $A_{1} B_{2}$ & $A_{1} B_{3}$ \\
Discovery Learning $\left(A_{2}\right)$ & $A_{2} B_{1}$ & $A_{2} B_{2}$ & $A_{2} B_{3}$ \\
Conventional learning with android application $\left(A_{3}\right)$ & $A_{3} B_{1}$ & $A_{3} B_{2}$ & $A_{3} B_{3}$ \\
\hline
\end{tabular}

The moderator variable in this study is independent learning which is divided into 3 categories, high, medium, and low levels of independent learning. To categorize the level of independent learning, the magnitude of the interval is determined by the following formula [21].

$$
i=\frac{M x S-M n S}{N}
$$


With:

$i \quad$ : interval

$M x S$ : Maximum Score

$M n S$ : Minimum Score

$N \quad$ : Number of Category

The instruments used in this research were test instruments and independent learning questionnaires. The test was used to measure student mathematics learning outcomes in the cognitive domain. This research also uses an independent learning questionnaire in the form of a Likert Scale with four answer choices, always, often, rarely, and never. The independent learning questionnaire items have been validated by experts, the results show that the independent learning questionnaire is feasible to use. The prerequisite tests conducted were normality test and homogeneity test. Hypothesis testing uses two-way variance analysis using $3 \times 3$ factorial design.

\section{RESULTS AND DISCUSSION}

The treatment given to the experimental class is the application of Discovery Learning model that requires students to find information about a topic or concept and draw conclusions from that information, so that, the concepts they received will last long in their memory. The learning stages applied in this study are: [22]

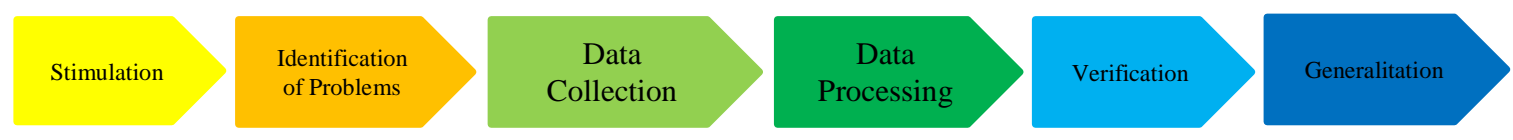

Figure 2. Discovery Learning Stages

In the stimulation stage, students are faced with problems that practice the ability to remember (remember-C1), then, in the problem identification stage, students identify the relevant problem to be used as a temporary answer (understand-C2). In the data collection stage, students collect information from various sources or do their own experiments, then, in the data processing stage, students apply and process the results of information obtained at the previous stage (applying C3, analyzing C4). At the verification level, students prove the data by examining it carefully and generalizing it (evaluating C5, creating C6). The difference in the results of student answers is shown in Table 2 below.

"Problems: Students are asked to formulate the nth term and determine the 10th term of the sequence of 81, 27, 9,3,... (Cognitive Question C5-Evaluating)"

Table 2. Students Answers

\begin{tabular}{|c|c|c|}
\hline $\begin{array}{l}\text { Discovery Learning with } \\
\text { Android Application } \\
\text { (Experimental Class 1) } \\
\end{array}$ & $\begin{array}{c}\text { Discovery Learning } \\
\text { (Experimental Class 2) }\end{array}$ & $\begin{array}{c}\text { Conventional Learning with } \\
\text { Android Application } \\
\text { (Control) } \\
\end{array}$ \\
\hline $\begin{array}{l}\text { Based on the question, we } \\
\text { knew: }\end{array}$ & $\begin{array}{l}\text { Based on the question, we knew: } \\
U_{1}=a=81\end{array}$ & $\begin{array}{l}\text { Based on the question, we } \\
\text { knew: }\end{array}$ \\
\hline$a=81=3^{4}$ & $U_{2}=27, U_{3}=9, U_{4}=3$ & Numbers $81,27,9,3$ \\
\hline$r=\frac{27}{81}=\frac{1}{3}=3^{-1}$ & So, we will use $U_{n}$ and $U_{10}$ formula: & $\begin{array}{l}\text { So, we will use } U_{n} \text { and } U_{10} \\
\text { formula: }\end{array}$ \\
\hline$U_{n}=a r^{n-1}$ & $U_{n}=a r^{n-1}$ & $\begin{array}{l}U_{1}=a=81, U_{2}=27, U_{3}=9 \\
U_{4}=3\end{array}$ \\
\hline$U_{n}=3^{4} \times\left(3^{-1}\right)^{n-1}$ & $U_{n}=81 \times\left(\frac{1}{3}\right)^{n-}$ & $b=U_{2}-U_{1}=-54$ \\
\hline
\end{tabular}




$$
\begin{aligned}
U_{n} & =3^{4} \times(3)^{-n+1} \\
U_{n} & =3^{4-n+1} \\
U_{n} & =3^{5-n} \\
U_{10} & =3^{5-10} \\
& =3^{-5} \\
& =\frac{1}{3^{5}} \\
U_{10} & =\frac{1}{243}
\end{aligned}
$$

$$
\begin{aligned}
U_{10} & =81 \times\left(\frac{1}{3}\right)^{10-1} \\
& =81 \times\left(\frac{1}{3}\right)^{9} \\
& =81 \times \frac{1}{19683} \\
U_{10} & =\frac{1}{243}
\end{aligned}
$$

(b)

$$
\begin{aligned}
U_{n} & =a+(n-1) b \\
& =81+(n-1)(-54) \\
& =81+(-54 n+54) \\
U_{n} & =135-54 n \\
U_{10} & =135-54.10 \\
& =135-540 \\
U_{10} & =-450
\end{aligned}
$$

(c)

In experimental class $1,82,86 \%$ (29 out of 35 students) successfully solved the mathematical problem, one of the students' answers in experiment class 1 was shown in column a. Whereas in the experimental class 2 , only $81,25 \%$ (25 out of 32 students) succeeded in solving the problem, example of the students' answers in experiment class 2 were seen in column b. But in the control class, $67.65 \%$ (23 out of 34 students) were not able to distinguish arithmetic or geometric sequences, so, students made mistakes in using concepts in solving problems. 23 students in the control class used the concept of arithmetic sequence on the geometric sequence problem. Because in conventional learning, all concepts are the results of teacher explanations, students are considered to be empty bottles or white paper so that the transfer of knowledge goes one way. While in Discovery learning, learning will be meaningful because students are given a stimulus to identify, collect, and process information in solving mathematical problems, so, the concepts obtained will last long in memory [23]. Table 3 is data on student mathematics learning outcomes in the cognitive domain:

Table 3. Learning Outcome Results

\begin{tabular}{ccccc}
\hline \multirow{2}{*}{ Class } & \multicolumn{4}{c}{ Statistic } \\
\cline { 2 - 5 } & $\begin{array}{c}\text { Average } \\
\text { Score }\end{array}$ & $\begin{array}{c}\text { Minimum } \\
\text { Score }\end{array}$ & $\begin{array}{c}\text { Maximum } \\
\text { Score }\end{array}$ & Total \\
\hline $\begin{array}{c}\text { Discovery Learning Model Learning with } \\
\text { Android Application }\end{array}$ & 77,886 & 55 & 96 & 35 \\
$\begin{array}{c}\text { Discovery Learning Model } \\
\begin{array}{c}\text { Conventional Learning Model with Android } \\
\text { Application }\end{array}\end{array}$ & 75,344 & 51 & 93 & 32 \\
\hline
\end{tabular}

Based on table 3, we can conclude that the average score of students' learning outcomes in experimental class 1 is higher than the average of students' learning outcomes in experimental class 2 and control class. And the average score of students in the experimental class 2 is higher than the average score of students in the control class. The hypothesis in this study is:

Signification test:

$$
\begin{aligned}
& \mathrm{H}_{0}: \sigma_{1}^{2}=\sigma_{2}^{2}=\sigma_{3}^{2}=\cdots=\sigma_{a}^{2} \\
& \mathrm{H}_{\mathrm{a}}: \exists \sigma_{i}^{2}=\sigma_{i^{\prime}}^{2}, i \neq i^{\prime}, i=1,2,3, \ldots, a
\end{aligned}
$$

$\mathrm{F}_{\text {count }}>\mathrm{F}_{\text {table }}: \mathrm{H}_{0}$ is rejected, it means there is a difference in variance

$\mathrm{F}_{\text {count }}<\mathrm{F}_{\text {table }}: \mathrm{H}_{0}$ is accepted, that means all variances are the same

Hypothesis testing uses two-way variance analysis, the results of the analysis are shown in Table 4 below.

148 Indonesian Journal of Science and Mathematics Education ( I J S M E ) 
Table 4. Test Results of Analysis of Two-Way Variance Dependent Variable: Student Learning Outcomes in the Cognitive Domain

\begin{tabular}{lrrrrr}
\hline \multicolumn{1}{c}{ Source } & $\begin{array}{c}\text { Type III Sum of } \\
\text { Squares }\end{array}$ & Df & Mean Square & \multicolumn{1}{c}{ F } & \multicolumn{1}{c}{ Sig. } \\
\hline Corrected Model & $5169.793^{\mathrm{a}}$ & 8 & 646.224 & 9.648 & 0.000 \\
Intercept & 556719.421 & 1 & 556719.421 & 8311.476 & 0.000 \\
Learning_Model & 423.366 & 2 & 211.683 & 3.160 & 0.047 \\
Independent_Learning & 4215.143 & 2 & 2107.572 & 31.465 & 0.000 \\
Learning_Model * & 301.356 & 4 & 75.339 & 1.125 & 0.350 \\
Independent_Learning & & & & & \\
Error & 6162.346 & 92 & 66.982 & & \\
Total & 582010.000 & 101 & & & \\
Corrected Total & 11332.139 & 100 & & & \\
\hline
\end{tabular}

a. $\mathrm{R}$ Squared $=.456$ (Adjusted R Squared $=.409$ )

Based on Table 4 above, the $\mathrm{F}_{\text {count }}$ value obtained for the Discovery Learning model is 3,160 . If we compare $F_{\text {ccount }}$ and $F_{\text {table }}=3,09$ we will get $F_{\text {count }}>F_{\text {table }}$ or 3,160 > 3,09 . So, it can be concluded that there are differences in average scores on student mathematics learning outcomes. The significance value obtained for students' independent learning variable is 0,000 , smaller than the significance value of 0,05 so $\mathrm{H}_{0}$ is rejected. $\mathrm{F}_{\text {count }}$ for learning model*independent learning is 1,125. If we compare between $F_{\text {count }}$ and $F_{\text {table }}=2,46$, we will get $F_{\text {count }}<F_{\text {table }}$ or $1,125<2,46$. The significance value obtained for learning model*student independent learning is 0,350 which is greater than 0,05 , so $\mathrm{H}_{0}$ is rejected. So, it can be concluded that there is no interaction between Discovery Learning model and the level of student independent learning towards student mathematics learning outcomes.

The outcomes of mathematics learning in experimental class 1 and the control class show that Discovery Learning model has a higher impact compared to conventional model. Suphi's research showed that there is a significant and positive relationship between Discovery Learning and student homework based on the cognitive domain of Bloom's Taxonomy [24]. Therefore, the application of Discovery Learning can improve student learning outcomes in the cognitive domain. Discovery learning is feasible to be applied to mathematics learning because it has a better effect on learning outcomes. Through this learning, student knowledge is built using discovery techniques in learning and will last longer in students' memories [25]. After students learn with Discovery Learning, students are able to express mathematical language coherently, students' independent learning competencies develop clearly, and students become more interested in learning mathematics [26]. Student learning success is also influenced by various factors involved in all learning activities, including internal factors within students. Good learning outcomes are influenced by the attitude of students who have an awareness on learning, so, they are responsible during the learning process [27].

Independent learning is the process of controlling oneself to learn not to depend on others, being able to take decisions and initiatives to overcome problems without expecting help from others, and having confidence in carrying out tasks. The results of the independent learning test in this study indicated there are differences in mathematics learning outcomes between students who have high, medium and low independent learning. Students who get high mathematics learning outcomes have high and medium category independent learning. While students who get low mathematics learning outcomes are students who have low independent learning category [28]. This is because students who have high independence will not easily give up, believe in their own abilities, try earnestly to pursue learning achievement, and are ready to overcome any problems. So 
it can be concluded that the personality of a student who has independent learning has a positive effect on good learning outcomes.

Discovery learning makes learning focused on students, because the teacher only acts as a guide and facilitator, students who must try to find their own concepts to hone students' scientific thinking skills [29]. Previous research has revealed that students who have high independent learning are suitable to use the Discovery Learning learning model, because this learning model requires students to be active in constructing knowledge [30]. While students who have low independent learning will easily adapt to conventional learning models, this is because students with low levels of independent learning tend to have low curiosity [31]. Hypothesis test result explains that there is no influence on the use of learning models and independent learning on student mathematics learning outcomes. This is in line with Prasetyo's research which also did not find any interaction between the learning model with the independence of student learning towards student mathematics learning outcomes [32].

\section{CONCLUSION}

Based on the results of the study, it can be concluded that (1) There is a difference in mathematics cognitive skills of students who learn by using the Discovery Learning model assisted with Android applications, using the discovery learning model only, and using conventional learning model assisted by Android application. Discovery learning assisted by android application made students in experimental class 1 class got an average score that is higher than students in experimental class 2 who learned with discovery learning model only or students in the control class who learned with conventional learning model assisted by Android application. (2) There is a difference in the average score of mathematics cognitive skills between students who have high, moderate, and low independent learning skills. (3) There is no effect on the interaction between the Discovery Learning model and students' independent learning on mathematics cognitive skills.

\section{REFERENCES}

[1] Ismail. NR, Mudjiran, Neviyarni. "Membangun Karakter Melalui Implementasi Teori Belajar Behavioristik Pembelajaran Matematika Berbasis Kecakapan Abad 21”. Jurnal Menara Ilmu, Vol. XIII, No. 11, pp.76-88, 2019.

[2] Sutama. "Pengelolaan Pembelajaran Matematika Sekolah Standar Nasional". Jurnal Ilmiah Pendidikan Matematika. Vol. 1, No.1, pp. 1-15, 2013.

[3] Harahap, H.D, Richanatus, S. "Studi Kasus Kesulitan Belajar Matematika Pada Remaja”. Jurnal Psikologi, Vol. 11, pp. 20-30, 2015.

[4] Putri, E. N. "Peningkatan Keaktifan dan Hasil Belajar Melalui Model Pembelajaran Discovery". Trihayu: Jurnal Pendidikan Ke-SD-an, Vol. 4, No.2, pp. 369-374. 2018.

[5] Gazali, R.Y. "Pembelajaran Matematika yang Bermakna". Jurnal Pendidikan Matematika: Math Didactic. Vol. 2, No. 3, pp. 181-190, 2016.

[6] Rahman. A.A, Strategi Belajar Mengajar Matematika. Banda Aceh: Syiah Kuala University Press, 2018.

[7] Baharudin dan Esa N.W, Teori Belajar \& Pembelajaran, Yogyakarta: Ar-Ruzz Media, 2010.

[8] Siregar, Y. "Kompetensi Guru Dalam Bidang Strategi Perencanaan dan Pembelajaran Matematika.” Jurnal Formatif. Vol. 3, No 1, pp. 39-48. 2013.

[9] Swaak, J., Jongw, T. \& Joolingen, W. R.. The Effects of Discovery Learning and Expository Instruction on The Acquisition of Definitional and Intuitive Knowledge.

150 Indonesian Journal of Science and Mathematics Education 
Journal of Computer Assisted Learning, pp 225. Telematica Instituut,PO Box 589, 7500 AN Enschede, The Netherlands, 2004.

[10] Waterman. S. The Effects of Brainscape ${ }^{\text {ee }}$ S Confidence-Based Repition on Two Adultes Performance on Knowledge-Based Quizzes. International Jornal online[https:dspace.sunyconnect.suny.edu/bitstream/handle/1951/63066/Sarabeth_ Waterman_Masters_Project_May2013.pdf?sequence=1], 2013.

[11] Arifin, Z. "Perbandingan Model Pembelajaran Discovery Learning dan Talking Stick Terhadap Hasil Belajar.” Jurnal edureligia. Vol. 2, No.2, pp.77-81, 2018.

[12] Lestari, W. "Efektivitas Model Pembelajaran Guided Discovery Learning Terhadap Hasil Belajar Matematika." Jurnal SAP:Susunan Artikel Pendidikan. Vol. 2, No. 1, pp. 64-74, 2017.

[13] Winoto, Y.C, Tego, P. "Efektivitas Model Problem Based Learning dan Discovery Learning Terhadap KEmampuan Berpikir Kritis Siswa Sekolah Dasar." Jurnal Basicedu. Vol. 4, No. 2, pp. 228-238, 2020.

[14] Ningsih. R, Arfatin, N. "Pengaruh Kemandirian Belajar dan Perhatian Orang Tua Terhadap Prestasi Belajar Matematika." Jurnal Formatif, Vol. 6, No. 1, pp. 73-84, 2016.

[15] Handayani, N. Fauziah, H. "Hubungan Kemandirian Terhadap Hasil Belajar Siswa Mata Pelajaran Matematika di Kelas X SMK Kota Cimahi.” Jurnal On Education, Vol. 01, No. 02, pp. 1-8, 2018.

[16] Hidayah.L, Satrio. W, Ira. V, "Pengaruh Pembelajaran Reciprocal Teaching Terhadap HAsil Belajar MAtematika Ditinjau dari Kemandirian Belajar," Jurnal AKSIOMA, Vol. 8, No. 1, pp. 237-247, 2019.

[17] Azizah R, dkk, "Penerapan Problem Based learning pada materi Luas Permukaan Serta Volume Prisma dan Limas Ditinjau dari Kemandirian Belajar Siswa Kelas VIII SMP Negeri 2 Banyudono", Jurnal Pendidikan Matematika dan Matematika (JPMM). Vol. II, No. 4. pp. 298-306, 2018.

[18] Ningsih, F, Mardiyana, Gatut I, "Eksperimentasi Model Pembelajaran Kooperatif Tipe Team Assisted Individualization (TAI) Dengan Metode Snowball Drilling TErhadap Perestasi Belajar Matematika Ditinjau dari Kemandirian Belajar," Jurnal elektronik Pembelajaran Matematika. Vol. 2. No. 7, pp. 758=7770, 2014.

[19] Anggaini. D, Miftahul. F, Denny. S “ Pengaruh Evaluasi Tes Formatif Terhadap Hasil Belajar Matematika Ditinjau dari Tingkat Kemandirian Belajar Mahasiswa STT-PLN Jakarta Dengan Menggunakan Analisis Varian Anova", Jurnal Kilat, Vol. 7, No. 2, pp.100-108, 2018.

[20] Creswell, J.C, Education Research, Planning, Conducting and Evaluating Quantitative and Qualitative. ${ }^{\text {th }}$ Edition. Boston: Pearson, 2012.

[21] Sugiyono, Metode Penelitian Kuantitatif, Kualitatif, dan R\&D. Bandung: Alfabeta, 2017

[22] Ratumanan, Inovasi Pembelajaran: Mengembangkan Kompetensi Peserta Didik Secara Optimal. Yogyakarta: Penerbit Ombak, 2015.

[23] Liestya, AD. Effie, EM. Ringki, A. "Perbandingan Hasil Belajar Matematika Antara Model Discovery Learning dan Ekspositori Materi Segiempat dan Segitiga."Jurnal Pendidikan Matematika Raflesia. Vol. 5, No.2, pp. 103-112, 2020.

[24] Suphi, N. Huseyin, Y. "Effect Of Discovery Learning and Student Assessment On Academic Succes." Tojet: The Turkish Online Journal of Educational Technology, pp. 829-835, 2016. (Akses: 06 Juli 2020) 
[25] Yang, E.F.Y, dkk. "The Effectiveness of Inductive Discovery Learning in 1:1 Mathematics Classroom." Proc. International Conference on Computers in Education. pp. 743-747, 2010.

[26] Tran, T, dkk. "Discovery Learning with the Help of the GeoGebra Dynamic Geometry Software." International Journal of Learning, Teaching and Educational Research, Vol. 7, No. 1, pp. 44-57, 2014.

[27] Bungsu, TK. dkk. "Pengaruh Kemandirian Belajar Terhadap Hasil Belajar Matematika di SMKN 1 Cihampelas." Jurnal On Education, Vol. 01, No. 02, pp. 382-389, 2019.

[28] Woi, M.F, Yuli, P. "Hubungan antara Kemandirian Belajar dengan HAsil Belajar Matematika." Jurnal Teacher in Education Research, Vol. 1, No. 1, pp. 1-8, 2019.

[29] Nursuprianah, I. Elis, L. "Perbandingan Hasil Belajar Matematika Siswa Antara yang Menerapkan Metode Discovery Learning dengan yang Menerapkan Metode Inquiry pada Pokok Bahasan Segiempat.” Jurnal EduMa, Vol. 3, No. 2, pp. 19-33, 2014.

[30] Yulietri, F. Mulyoto, Leo Agung. "Model Flipped Classroom dan Discovery Learning: Pengaruhnya Terhadap Prestasi Belajar Matematika Ditinjau dari Kemandirian Belajar.” Jurnal Teknodika. Vol. 13, No. 2, pp. 5-17, 2015.

[31] Astuti, ND. "Pengaruh Metode Terhadap Hasil Belajar Matematika Ditinjau dari Kemandirian Belajar Siswa.” Jurnal Elementary. Vol. 1, No. 2, pp. 31-35, 2015

[32] Prasetyo, S. dkk. "Eksperimentasi Model Pembelajaran Discovery Learning (DL) dan Problem Based Learning (PBL) Pada Materi Bangun Ruang Ditinjau dari Kemandirian Belajar Siswa Kelas VIII SMP Negeri Se-Kabupaten Banyumas Tahun Pelajaran 2014/2015". Jurnal Elektronik Pembelajaran Matematika, Vol. 3, No. 9, pp. 997-1008, 2015. 